\title{
COMPARISON OF MATERNAL AND PERINATAL OUTCOME IN PREGNANT WOMEN WITH HYPOTHYROIDISM DIAGNOSED BEFORE CONCEPTION WITH HYPOTHYROIDISM DIAGNOSED DURING PREGNANCY
}

\author{
Basnet $\mathrm{P}^{1}$, Aggrawal N ${ }^{2}$, Suri $\mathrm{V}^{3}$, Dutta $\mathrm{P}^{4}$, Mukhopadhyay $\mathrm{K}^{5}$
}

\section{ABSTRACT}

BACKGROUND: Thyroid disorder is one of commonest endocrine disorder in women and hence constitutes a common endocrine disorder complicating pregnancy. Diagnosing and treating hypothyroidism preconceptionally and during early pregnancy appears to be a useful strategy to improve maternal and fetal outcome.

OBJECTIVE: To compare the maternal and perinatal outcome in pregnant women with hypothyroidism diagnosed preconceptionally with hypothyroidism diagnosed during pregnancy.

METHODS: A prospective study. One hundred pregnant women with hypothyroidism at less than 20 weeks Period of Gestation (POG) were recruited for the study and grouped into two groups: Group A-hypothyroidism diagnosed and on treatment before conception, Group B-hypothyroidism diagnosed and started on treatment during pregnancy. Both groups were intensively monitored during pregnancy with serial Thyroid Function Test (TFT) and thyroxine replacement doses were adjusted accordingly. Various maternal, perinatal and fetal outcome measures were studied in both groups prospectively till delivery.

RESULTS: The maternal and fetal complications were comparable in the two groups, however the fetal birth weight was significantly higher in Group A versus Group B $(2.89 \pm 0.485 \mathrm{~kg}$ vs. $2.70 \pm 0.453 \mathrm{~kg}$; $\mathrm{p}=0.039)$. All the new born babies had normal thyroid function.

CONCLUSION: Hypothyroidism diagnosed preconceptionally or during early pregnancy and treated appropriately has beneficial effect on fetal birth weight, and hence the total pregnancy outcome. Screening for thyroid dysfunction should be judiciously performed in all high risk women prior to a planned conception or during their first antenatal visit.

KEYWORDS: Hypothyroidism, Pregnancy, Thyroid peroxidise

1. Assistant Professor, Department of Obstetrics and Gynaecology, B.P. Koirala Institute of Health Sciences, Dharan, Nepal

2. Associate Professor, Department of Obstetrics and Gynaecology, Post Graduate Institute of Medical Education and Research, Chandigarh, India

3. Professor, Department of Obstetrics and Gynaecology, Post Graduate Institute of Medical Education and Research, Chandigarh, India

4. Assistant Professor, Department of Endocrinology, Post Graduate Institute of Medical Education and Research, Chandigarh, India

5. Additional Professor, Department of Neonatology, Post Graduate Institute of Medical Education and Research Chandigarh, India

\author{
For Correspondence \\ Dr. Pritha Basnet \\ Assistant Professor, \\ Department of Obstetrics and Gynaecology, \\ B.P.Koirala Institute of Health Sciences, Dharan, Nepal \\ Email: prithapep@yahoo.com
}




\section{INTRODUCTION}

Thyroid disorder is one of the commonest endocrine disorders in women and hence constitutes the commonest endocrine disorder complicating pregnancy. Hypothyroidism both overt and subclinical is common in women of reproductive age and during pregnancy with frequency ranging from $0.35 \%$ to $2.5 \%$.

Pregnancy induces normal physiological changes that affect thyroid function and thyroid function testing. Increased renal blood flow and glomerular filtration rate lead to an increase in the excretion of plasma iodide, and as a result dietary iodide requirement is increased in pregnancy. Second, because of broad structural homology between the alpha subunits of both Thyroid Stimulating Hormone (TSH) and Human Chorionic Gonadotropin(hCG), hCG has an intrinsic weak thyroid stimulating effect. At the end of first trimester, up to one fifth of euthyroid pregnant women will exhibit a small and transient increase in free Thyroxine $\mathrm{T} 4$ levels and a partial TSH suppression. During the remainder of the pregnancy, serum TSH level returns to the generally accepted normal range of $0.4-4.0 \mathrm{mIU} / \mathrm{L}$. During pregnancy, there is an increase in total Thyronine $\mathrm{T} 3$ and total $\mathrm{T} 4$ due to increased thyroid binding globulin (TBG) concentration. Increased plasma volume, along with increased TBG, results in increased production of total T4. By 4 to 6 weeks postpartum, serum TBG, T4 and T3 return to prepregnancy levels.Morbidity of hypothyroidism during pregnancy is significant ${ }^{2}$. Untreated or inadequately treated and subclinical hypothyroidism are all associated with increased risk of miscarriage, preeclampsia, anaemia, fetal growth restriction, placental abruption, perinatal and neonatal morbidity and mortality (preterm delivery, small head circumference, low birth weight, impaired neuropsychological development ). ${ }^{3,4}$

Several studies have found that not only is overt hypothyroidism associated with maternal and fetal adverse consequences but also subclinical hypothyroidism or euthyroidism in patients affected by thyroid autoimmunity may adversely affect the mother or fetus. ${ }^{5,6}$ Positive thyroid peroxidase antibodies (TPO) even with normal thyroid function test during pregnancy are associated with an increased risk of developing postpartum thyroiditis. ${ }^{7}$

Pregnancy modifies the clinical state of the disease and alters the thyroid function tests. For this reason hypothyroid women treated with levothyroxine need to increase their daily levothyroxine doses during pregnancy .In both treated and untreated hypothyroid women, a rise in serum TSH levels indicates a worsening of the situation and therefore TSH should be monitored every $4-6$ weeks. ${ }^{8.9}$ The optimal timing to increase levothyroxine is the $1^{\text {st }}$ trimester of pregnancy. Levothyroxine administration, at doses that maintain optimal TSH level, greatly decrease the frequency of obstetric complications, thus suggesting that any pregnant women should be screened for the possible presence of hypothyroidism. ${ }^{10,11}$

Since hypothyroidism is easily treated, timely detection and treatment of the disorder could reduce the burden of maternal and perinatal outcome.

The purpose of study was to prospectively evaluate and compare the maternal and perinatal outcome of pregnant women who were already diagnosed hypothyroidism preconceptionally, in comparison to those diagnosed during index pregnancy.

\section{METHODS}

This Prospective study was carried in the Department of Obstetrics and Gynaecology during the time June 2008 to December 2009. One hundred pregnant women with hypothyroidism during the period were recruited for the study and grouped into 2 (50 women in each group) according to the time of diagnosis of hypothyroidism. The study was started after obtaining ethical clearance from the Institute Ethical Review Board.

\section{Inclusion Criteria}

1. Pregnant women who were diagnosed to have hypothyroidism stabilised on thyroxine replacement therapy before pregnancy (group A)

2. Pregnant women who were diagnosed to have hypothyroidism during pregnancy (group B)

3. Gestational age $<20$ weeks

\section{Exclusion criteria}

1. Pregnant women with any other concomitant medical disorder

2. Failure to follow up or delivering elsewhere other than PGIMER

Detailed obstetric history and history regarding the onset of the thyroid illness, symptoms and the course of the illness including the drug dosage details were recorded for each 
woman. Thyroid function test was done by Immuno chemiluminiscence analyser in the Department of Endocrinology at PGIMER. The reference range used for T3, $\mathrm{T} 4$, TSH and TPO was $0.8-2.0 \mathrm{ng} / \mathrm{ml}, 4.8-12.7 \mu \mathrm{g} / \mathrm{dl}, 0.27-$ $4.2 \mu \mathrm{IU} / \mathrm{ml}$ and $34 \mathrm{IU} / \mathrm{ml}$ respectively.

Pregnant women were then divided into two categories based on whether their hypothyroidism was detected before or during pregnancy. Both group of women underwent TFT which included T3, T4 and TSH and thyroid peroxidase antibody at the time of recruitment to the study. TFT was repeated every 6-8 weekly during pregnancy. Subsequent dose titration, if required was done according to the follow up TFT. Any dose modification was recorded in the proforma.

\section{Antenatal follow up}

Maternal and fetal surveillance was done according to the routine protocol in the department.. Development of any complication in the antenatal period was noted. Admission was done for any maternal or fetal indication. Pregnancy was allowed to continue till 40 weeks period of gestation, unless termination was indicated due to maternal or fetal indication.

\section{Delivery and Neonatal details}

Details of the mode of delivery and any intrapartum or postpartum complications were noted. Thyroid function test of all neonates was done at 72 hours of life and babies were followed up till discharge. The reference range used for neonatal $\mathrm{TSH}<20 \mu \mathrm{IU} / \mathrm{ml}$.

\section{Outcome measures}

\begin{tabular}{|c|c|}
\hline Maternal complications & Neonatal outcome \\
\hline $\begin{array}{ll}\text { - } & \text { Spontaneous abortion } \\
\text { - } & \text { Hypertensive } \\
& \text { complications ( gestational } \\
& \text { hypertension ,pre- } \\
& \text { eclampsia and eclampsia) } \\
\text { - } & \text { Gestational diabetes } \\
\text { - } & \text { Anellitus } \\
\text { - Intepartum hemorrhage } \\
\text { - Preterm labour } \\
\text { - Postpartum haemorrhage }\end{array}$ & $\begin{array}{ll}\text { - } & \text { Prematurity (definition: } \\
& \text { Delivery between 28- } \\
& 37 \text { weeks ) } \\
\text { - } & \text { Birth weight } \\
\text { - } & \text { Congenital malformation } \\
\text { - Neonatal goitre } \\
\text { - Neonatal jaundice } \\
\text { - Neonatal unit admission } \\
\text { - Neonatal death } \\
\text { - Neonatal thyroid profile }\end{array}$ \\
\hline
\end{tabular}

\section{STATISTICAL ANALYSIS}

All data was stored in Microsoft Excel format and was analysed in SPSS version 17. Chi-square test was used for categorical data and Student's $t$ test was used for continuous data. Independent sample $\mathrm{T}$ test was used to compare the means. Mann Whitney U test was used for continuous data when it did not show a normal distribution. Ap value of less than 0.05 was taken as significant.

\section{RESULTS}

The age distribution of the women in the two groups was statistically comparable. Majority of the patients were in the age group of 25-29 yrs with a mean age of $28.54 \pm 4.272$ years in group A and $27.88 \pm 3.931$ years in group B. $(\mathrm{p}$ value= $0.543)$.

The weight distribution of the pregnant women in both groups was also statistically comparable. The mean weight was $60.28 \pm 6.898 \mathrm{~kg}$ in group A and $60.82 \pm 7.107 \mathrm{~kg}$ in group B. (p value $=0.701$ )

Multiparous women comprised of maximum number of patients in both groups, $74 \%$ in group $\mathrm{A}$ and $58 \%$ in group B. Thyroid peroxidase antibody positivity was also comparable in the two groups, $52 \%$ in group A and $66 \%$ in group B as shown in Table 1.

\section{Table1: Distribution of Thyroid peroxidase antibody} (TPO)

\begin{tabular}{|l|l|l|}
\hline TPO & Group A $(\mathbf{n}=\mathbf{5 0})$ & Group B $(\mathbf{n}=\mathbf{5 0})$ \\
\hline Positive & $26(52 \%)$ & $33(66 \%)$ \\
\hline Negative & $24(48 \%)$ & $17(34 \%$ \\
\hline
\end{tabular}

$\mathrm{p}=\mathbf{0 . 1 5 5}$

The mean T4 level in group A was greater in $2^{\text {nd }}$ and $3^{\text {rd }}$ trimester as compared to group B (after the start of treatment) as shown in Table 2 . The $2^{\text {nd }}$ trimester mean TSH value was also statistically significant $(\mathrm{p}=0.035)$. However in $3^{\text {rd }}$ trimester the mean TSH was comparable in both the groups as shown in Table 3.

Table 2: Mean T4 level during pregnancy

\begin{tabular}{|l|l|l|l|}
\hline & $\begin{array}{c}\text { Group A(n } \\
=\mathbf{5 0}) \\
\mathbf{T 4}(\boldsymbol{\mu g} / \mathbf{d l})\end{array}$ & $\begin{array}{c}\text { Group } \\
\mathbf{B}(\mathbf{n}=\mathbf{5 0}) \\
\mathbf{T 4}(\boldsymbol{\mu} \mathbf{g} / \mathbf{d l})\end{array}$ & P value \\
\hline Ist trimester & $10.547 \pm 2.859$ & $8.0129 \pm 1.758$ & 0.000 \\
\hline $2^{\text {nd }}$ trimester & $11.523 \pm 7.479$ & $10.521 \pm 9.161$ & 0.551 \\
\hline $3^{\text {rd }}$ trimester & $11.780 \pm 2.644$ & $\begin{array}{l}10.833 \pm \\
2.935\end{array}$ & 0.093 \\
\hline
\end{tabular}


Table 3: Mean THS value in different trimsesters of pregancy

\begin{tabular}{|l|l|l|l|}
\hline & $\begin{array}{l}\text { Group A }(\mathbf{n}=\mathbf{5 0}) \\
\text { TSH }(\boldsymbol{\mu} \mathbf{I U} / \mathbf{m l})\end{array}$ & $\begin{array}{l}\text { Group B(n=50) } \\
\text { TSH }(\boldsymbol{\mu I U} / \mathbf{m l})\end{array}$ & p value \\
\hline $1^{\text {st }}$ trimester & $3.67 \pm 3.935$ & $10.50 \pm 8.444$ & 0.000 \\
\hline $2^{\text {nd }}$ trimester & $3.12 \pm 2.836$ & $5.07 \pm 5.785$ & 0.035 \\
\hline $3^{\text {rd }}$ trimester & $1.69 \pm 1.107$ & $1.92 \pm 1.274$ & 0.340 \\
\hline
\end{tabular}

The mean thyroxine requirement in group $\mathrm{A}$ was $76.25 \pm 25.032 \mu \mathrm{g} /$ day before pregnancy. The mean thyroxine requirement in $1^{\text {st }}, 2^{\text {nd }}$ and $3^{\text {rd }}$ trimester was $92.75 \pm 29.783 \mu \mathrm{g} /$ day, $105.25 \pm 34.264 \mu \mathrm{g} /$ day and $109.75 \pm 34.928 \mu \mathrm{g} / \mathrm{day}$ respectively as shown in Table 4.

In group $B$ the mean thyroxine requirement was $62.50 \pm 19.022 \mu \mathrm{g} / \mathrm{day}, 72.50 \pm 23.690 \mu \mathrm{g} / \mathrm{day}$ and $81.25 \pm 28.149 \mu \mathrm{g} /$ day in $1^{\text {st }}, 2^{\text {nd }}, 3^{\text {rd }}$ trimester respectively. The mean increment in thyroxine dose from the pre-pregnant state in group $\mathrm{A}$ was $21.63 \%, 38.03 \%, 43.93 \%$ in $1^{\text {st }}, 2^{\text {nd }}, 3^{\text {rd }}$ trimester respectively and the increment was statistically significant $(\mathrm{p}<0.05)$ in all the trimester. In group B the mean increment in thyroxine dose since the time of diagnosis was $16.00 \%$ and $30.00 \%$ in $2^{\text {nd }}$ and $3^{\text {rd }}$ trimester respectively and was statistically significant $(\mathrm{p}<0.05)$ as shown in Table 4.

\section{Table 4: Mean thyroxine requirement in different} trimesters

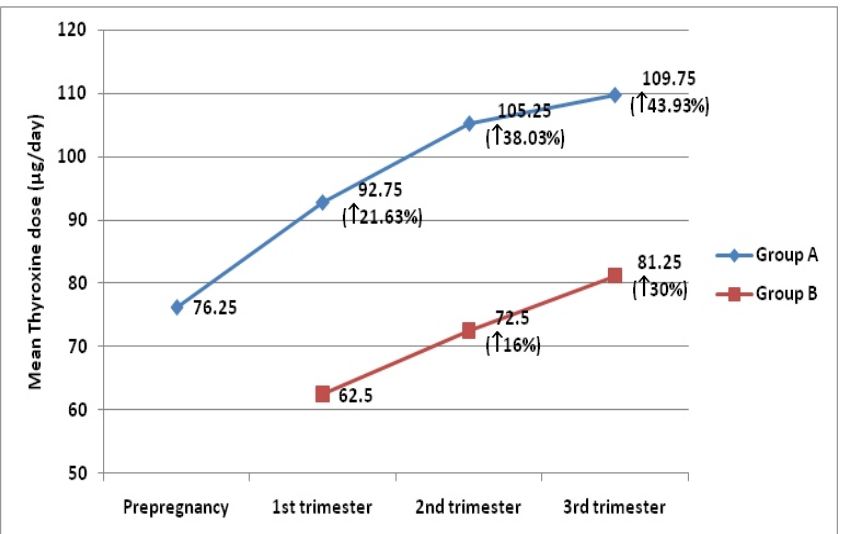

The gestational age at the time of delivery was comparable in both the groups. Majority of them delivered at term, $92 \%$ in group A and $84 \%$ in group B respectively $(\mathrm{p}=0.218)$. Mode of delivery was comparable in the two groups. The pregnancy related complications were also similar among the two groupsas shown in Table 5.
Table 5: Maternal Complications

\begin{tabular}{|l|l|l|l|}
\hline Complications & $\begin{array}{l}\text { Group } \\
\text { A(n=50) }\end{array}$ & $\begin{array}{l}\text { Group } \\
\text { B(n=50) }\end{array}$ & p value \\
\hline PIH & $12(24 \%)$ & $6(12 \%)$ & 0.118 \\
\hline Preterm labour & $2(4 \%)$ & $3(6 \%)$ & 0.646 \\
\hline PTPROM & $1(2 \%)$ & $2(4 \%)$ & 0.558 \\
\hline GDM & $3(6 \%)$ & $1(2 \%)$ & 0.079 \\
\hline Cholestasis & $4(8 \%)$ & $7(14 \%)$ & 0.338 \\
\hline
\end{tabular}

The mean birth weight in group A was $2.89 \pm 0.485 \mathrm{~kg}$ and in group B was $2.70 \pm 0.453 \mathrm{~kg}$ and was statistically significant $(\mathrm{p}=0.039)$. The majority of the new borns were appropriate for dates, $84 \%$ in group $\mathrm{A}$ and $82 \%$ in group B.Neonatal hyperbilirubinemia was also comparable in both the groups. The thyroid profile of the new born babies was normal in the studyas shown in Table 6.

Table 6: Perinatal Outcome

\begin{tabular}{|l|l|l|l|}
\hline & $\begin{array}{l}\text { Group } \\
\text { A(n=50) }\end{array}$ & $\begin{array}{l}\text { GroupB } \\
(\mathbf{n = 5 0 )}\end{array}$ & p value \\
\hline Mean Birthweight $(\mathrm{kg})$ & $2.89 \pm 0.485$ & $\begin{array}{l}2.70 \pm 0.45 \\
3\end{array}$ & 0.039 \\
\hline Small for dates & $5(10 \%)$ & $8(16 \%)$ & 0.426 \\
$\begin{array}{l}\text { Neonatal } \\
\text { Hyperbilirubinemia }\end{array}$ & $14(28 \%)$ & $7(14 \%)$ & 0.086 \\
\hline Mean TSH $(\mu \mathrm{IU} / \mathrm{ml})$ & $2.95 \pm 2.025$ & $\begin{array}{l}2.99 \pm 2.12 \\
8\end{array}$ & 0.910 \\
\hline
\end{tabular}

\section{DISCUSSION}

Thyroid hormone secretion physiologically increases during pregnancy to meet the increased requirement of the pregnant mother as well as the growing fetus. Women with marginally low thyroid function might not be able to meet this increase physiological demand, leading to its adverse consequences.

Women on adequate replacement of thyroxine, during preconception and in early pregnancy, should expect a good obstetric outcome than in those who start treatment in late second trimester. 
The characteristics of patients in group A and group B were statistically comparable in relation to age and weight.

In our study, majority of the women were multiparous in both groups. The parity distribution in other studies was similar to the present study.

The rate of TPO positivity was more in group B as compared to group A with a p value of 0.155 . The slightly higher rate of TPO positivity in group B could be due to the inclusion of TPO positive women who had significantly higher antibody titres, but normal thyroid hormones. In our study, there was no significant difference in obstetric outcome because both the groups were started on levothyroxine at the time of recruitment in the study which eliminated the possible adverse outcome related to untreated TPO positive cases.

Negro et al. ${ }^{12}$ studied whether TPO ab+ pregnant women had increased obstetrical complications in comparison to those with TPO ab-status and whether levothyroxine was beneficial to prevent these events. They divided their study population into three groups: Group A comprising of TPO $a b+$ women started on LT4, Group B comprising of TPO ab+ women not receiving LT4 and Group C comprising of TPO ab- women. They found that group $\mathrm{A}$ and group $\mathrm{C}$ had a similar miscarriage rate $(3.5 \%$ and $2.4 \%$ respectively), whereas group $\mathrm{B}$ had higher rate of pregnancy loss $(13.8 \% ; \mathrm{p}<0.05$, relative risk $=1.72 ; 95 \% \mathrm{CI}=1.13-2.25)$. Other obstetrical complications did not vary among the three groups.

The mean T4 value was greater in group A (hypothyroidism diagnosed before pregnancy) as compared to group B (hypothyroidism diagnosed during pregnancy) in $2^{\text {nd }}$ and $3^{\text {rd }}$ trimester. In women belonging to group A, hypothyroidism was diagnosed before pregnancy and were already on levothyroxine at the time of recruitment, hence their T4 level was higher as compared to the other group where hypothyroidism was diagnosed during pregnancy and then started on levothyroxine. This mean T4 value also showed that most of the women in group A had a well controlled thyroid profile.

The mean TSH value in $2^{\text {nd }}$ trimester was $3.12 \pm 2.836 \mu \mathrm{IU} / \mathrm{ml}$ and $5.07 \pm 5.785 \mu \mathrm{IU} / \mathrm{ml}$ respectively in the two groups (p $=0.035$ ). The mean TSH value in the present study was statistically significant in $2^{\text {nd }}$ trimester in between the group. However in $3^{\text {rd }}$ trimester the mean TSH value was comparable. This is obvious from the study that women who were diagnosed during pregnancy had a higher TSH level as compared to those who were diagnosed before pregnancy and controlled on thyroxine replacement therapy. After initiation of therapy the mean TSH was comparable in the $3^{\text {rd }}$ trimester. Till date, universal screening of women before or during pregnancy for thyroid dysfunction is not recommended. The general consensus is to test for serum TSH in women belonging to the high risk population preferably prior to pregnancy or in early gestation. ${ }^{13}$ The high risk population includes established hypothyroidism prior to pregnancy taking thyroxine therapy, personnel or family history of autoimmune thyroid disease, Type 1 diabetes mellitus and possible decreased thyroid gland reserve like history of neck irradiation and thyroidectomy.

In group $\mathrm{A}$, mean thyroxine requirement was $76.25 \pm 25.032 \mu \mathrm{g} /$ day in the prepregnant state. The mean thyroxine requirement in the $1^{\text {st }}, 2^{\text {nd }}$ and $3^{\text {rd }}$ trimester was $92.75 \pm 29.783 \mu \mathrm{g} / \mathrm{day}, \quad 105.25 \pm 34.264 \mu \mathrm{g} / \mathrm{day}$ and $109.75 \pm 34.928 \mu \mathrm{g} /$ day respectively. The mean thyroxine dose increment from prepregnant state was $21.63 \%, 38.03 \%$ and $43.93 \%$ in $1^{\text {st }}, 2^{\text {nd }}$ and $3^{\text {rd }}$ trimester respectively which was statistically significant $(\mathrm{p}<0.05)$. The result of the present study is consistent with the result of the study by Verga et al. where in $86.5 \%$ of patients already adequately treated before conception, levothyroxine dosage was increased at the first evaluation during pregnancy by $22.9 \pm 9.8 \mu \mathrm{g} /$ day. ${ }^{14}$

In group $B$, mean thyroxine requirement was $62.50 \pm 19.022 \mu \mathrm{g} / \mathrm{day}, \quad 72.50 \pm 23.690 \mu \mathrm{g} / \mathrm{day}$ and $81.25 \pm 28.149 \mu \mathrm{g} /$ day in $1^{\text {st }}, 2^{\text {nd }}$ and $3^{\text {rd }}$ trimester respectively. The mean dose increment from the baseline (from the time of diagnosis) was $16.00 \%(\mathrm{p}=0.000)$ and $30.00(\mathrm{p}=0.001)$ in $2^{\text {nd }}$ and $3^{\text {rd }}$ trimester respectively.

Alexander et al. ${ }^{15}$ in their study showed that levothyroxine requirement increases early during pregnancy in most women with primary hypothyroidism, and reaches a plateau after 16 to 20 weeks of gestation where the requirement becomes about $47 \%$ over and above the prepregnant state and then persist at the same level throughout pregnancy. In our study, both the groups showed a progressive increase in thyroxine dose from the baseline through all the trimester.

Although the current consensus is that thyroid function should be monitored every six to eight weekly during pregnancy, it appears that the increase in requirement ( up to 50 percent) of 
the levothyroxine dose peaks midway through pregnancy and remains constant thereafter, until delivery. ${ }^{16}$ Thyroidstimulating hormone is then measured at 68 week interval, and the levothyroxine dose is adjusted in $25-50 \mu \mathrm{g} /$ day increments. The therapeutic goal is to maintain TSH between 0.5 and 2.5 milli units/L.

\section{Maternal and perinatal outcome}

In the present study the majority of the women delivered at term in both the groups. The total number of preterm deliveries in group A and group B was $2(4 \%)$ and $3(6 \%)$ respectively; however this difference was statistically insignificant. Similar study by Mannisto et al. ${ }^{17}$ found no significant differences between the groups regarding preterm deliveries. Majority of the women delivered at a mean gestational age of 39.4 weeks in all the groups. In a study by Negro et al. ${ }^{12}$, TPO ab positivity was significantly related to preterm delivery, the rate of which decreased with levothyroxine treatment.

The maternal complications like pregnancy induced hypertension, gestational diabetes mellitus, preterm labour and cholestasis were comparable in the two groups $(\mathrm{p}>0.05)$ in our study. The outcome was similar to the study by Casey $\mathrm{BM}$ et $\mathrm{al}^{18}$ in which hypertensive complications, gestation at delivery and caesarean delivery rates were comparable $(\mathrm{p}>0.05)$.

The likelihood of complications depends upon the severity of the hypothyroidism and the adequacy of maternal treatment.

\section{Perinatal outcome}

In the study group the mean birth weight in group A was $2.89 \pm 0.485 \mathrm{~kg}$ and in group B it was $2.70 \pm 0.453 \mathrm{~kg}$ and was statistically significant $(\mathrm{p}=0.039)$. Since our study group consisted of hypothyroid mothers, one group diagnosed and already on thyroxine replacement therapy preconceptionally and the other group where hypothyroid was diagnosed during pregnancy and treatment started subsequently, it can be derived that preconceptionally diagnosed hypothyroidism was well controlled on thyroxine thus leading to the higher mean birth weight as compared to the other group. The gestation age at delivery was comparable in both the groups. Majority of them delivered at term( $92 \%$ vs $84 \%$ in group A and group B respectively). In the study by Blazer et al. ${ }^{19}$ where outcome of infants born to thyroxine replaced hypothyroid mothers was compared with euthyroid mothers, they found that the birth weight and head circumference was statistically smaller than the control group.

Another study by Tan et al. ${ }^{20}$ had shown that there was no statistically significant difference in birth weight between pregnant women with treated hypothyroidism as compared to the euthyroid mothers.

We support the work of Albovich et al. ${ }^{21}$ who suggested that the adequate treatment of hypothyroidism during gestation minimizes risks and generally makes it possible for pregnancies to be carried to term without added risk of complications.

Neonatal hyperbilirubinemia requiring phototherapy was more in babies born to group A mothers as compared to babies born to group B mothers but the difference was statistically insignificant (p0.086). Data regarding the association of neonatal hyperbilirubinemia in babies born to treated hypothyroid mothers are limited; hence more studies are required to corroborate the findings.

The mean TSH $(\mu \mathrm{IU} / \mathrm{ml})$ in the study $(2.95 \pm 2.025$ vs $4.21 \pm 9.348)$ was comparable among the two groups. In the study by Blazer et $\mathrm{al}^{22}$ significant correlation between maternal and neonatal TSH at $49 \mathrm{hrs}$ of life and older suggest that the fetal thyroid is affected by maternal thyroid status.

Increased requirement of thyroxine during pregnancy has to be considered by the treating obstetrician and once diagnosed, women should be monitored with serial TFT preferably every six weekly with adjustment of thyroxine doses as required in consultation with the endocrinologist. Though we are not in the position to advise screening of all pregnant women for thyroid dysfunction, considering its cost and benefit thyroid function test along with TPO has to be considered in high risk population as it has been found to have adverse maternal and perinatal outcome.

\section{CONCLUSION}

Though the maternal complication was comparable in the two groups, birth weight was significantly higher in those women where hypothyroidism was diagnosed before pregnancy as 
compared to those diagnosed during pregnancy. Our study has shown the effect of hypothyroidism on immediate neonatal outcome but long term studies are needed to evaluate the impact of hypothyroidism in pregnant women with neuropsycho intellectual development of the child.

Well controlled thyroid disease does not usually have major problems in pregnancy. Adequately treated hypothyroidism during pregnancy reduces the risk of adverse maternal and perinatal outcome to that of the general population. Comparable maternal and perintal outcome in both the groups could be the result of early replacement with levothyroxine in our study.

Our study also supports the importance of early diagnosis and treatment of women with hypothyroidism in pregnancy and also emphasizes on close monitoring of hypothyroid mothers with frequent testing of thyroid function and appropriate dose adjustment to have a favourable maternal and perinatal outcome.

\section{REFERENCES}

1. Idris I, Srinivasan $R$, Simm A, Page RC. Maternal hypothyroidism in early and late gestation: Effects on neonatal and obstetric outcome. Clin Endocrinol 2005 Nov; 63(5):560-5. http://dx.doi.org/10.1111/j.1365-2265.2005.02382.x PMid: 16268809

2. Brent GA. Maternal thyroid function: Interpretation of thyroid function tests in pregnancy. Clin Obstet Gynecol 1997Mar;40:3-15. http://dx.doi.org/10.1097/00003081-19970 3000-00004 PMid:9103946

3. Alvarez-Marfany $M$, Roman SH, Drexler AJ. Long-term prospective study of postpartum thyroid dysfunction in women with insulin dependent diabetes mellitus. J Clin Endocrinol Metab 1994;79:10-6. http://dx.doi.org/10.1210/jc.79.1.10 http:// dx.doi.org/10.1210/jcem.79.1.8027213 PMid:8027213

4. Neale D, Burrow G. Thyroid disease in pregnancy. Obstet Gynecol Clin North Am 2004 Dec; 31:893-905. http://dx. doi. org/10.1016/j.ogc.2004.09.001 PMid:15550341

5. DavisLE,LevenoKJ, Cunningham FG. Hypothyroidism complicating pregnancy. Obstet Gynaecol 1988;72:108-12. PMid:3380497

6. Glinoer D, Rihi M, Grun JP, Kinthaert J. Risk of subclinical hypothyroidism in pregnant women with asymptomatic autoimmune thyroid disorders. J Clin Endocrinol Metab 1994; 79:197-204.http://dx.doi.org/10.1210/jc.79.1.197http://dx. doi. org/10.1210/jcem.79.1.8027226 PMid:8027226

7. Bagis T, Gokcel A, Saygili ES. Autoimmune thyroid disease in pregnancy and the postpartum period: relationship to spontaneous abortion. Thyroid 2001;11:1049-53.http://dx. doi.org/10.1089/105072501753271743 PMid:11762715

8. Becks GP, Burrow GN. Thyroid disease and pregnancy. Med Clin North Am 1991;75,121-50. PMid:1987439

9. Kaplan MM. Monitoring thyroxine treatment during pregnancy. Thyroid 1992;2:147-52.http://dx.doi.org/10.1089/thy.1992.2. 147 PMid: 1525583

10. Mandel SJ, Spencer CA \&Hollowell JG. Are detection and treatment of thyroid insufficiency in pregnancy feasible? Thyroid 2005;15:44-53. http://dx.doi.org/10.1089/thy. 2005.15.44 PMid:15687823

11. Lazarus JH. Thyroid disorders associated with pregnancy: Etiology, diagnosis and management. Treat Endocrinol 2005;4: 31-41. http://dx.doi.org/10.2165/00024677-200504010-00004 PMid:15649099

12. Negro R, Formoso G, Mangieri T, Pezzarossa A, Dazzi D, Hassan H. Levothyroxine treatment in euthyroid pregnant women with autoinmune thyroid disease: Effects on obstétrical complications. J Clin Endocrinol Metab 2006;91:2587-91. http://dx.doi.org/10.1210/jc.2005-1603 PMid:16621910

13. Mandel SJ. Hypothyroidism and chronic autoimmune thyroiditis in the pregnant state: maternal aspects. Best Pract Res Clin Endocrinol Metab 2004 Jun;18(2):213-24 http://dx.doi.org /10.1016/j.beem.2004.03.006 PMid:15157837

14. Verga U, Bergamaschi S, Cortelazzi D, Ronzonit S, Marconit $A M$, Peccoz PB. Adjustment of L-T4 substitutive therapy in pregnant women with subclinical, overt or post-ablative hypothyroidism. Clin Endocrinol 2009;70:798-802. http:// dx. doi.org /10.1111/j.1365-2265.2008.03398.x PMid:18771569

15. Alexander EK, Marqusee E, Lawrence J, Jarolim P, Fisher GA, Larsen PR.Timing and magnitude of increases in Levothyroxine requirements during pregnancy in women with hypothyroidism. NEngl J Med 2004;351:241- 9. http://dx.doi.org /10.1056/NEJ Moa 040079 PMid:15254282

16. Surks MI, Ortiz E, Daniels GH, Sawin CT, Col NF, Cobin RH et al. Subclinical thyroid disease: scientific reviews and guidelines for diagnosis and management. JAMA 2004;291:228-38. http://dx. doi.org/10.1001/jama.291.2.228 PMid:1472215017.

17. Mannisto T, Varrasmaki M, Pouta A, Hartikainen A, Ruokenen A, Surcel H, BloiguAini, Jarvelin M, Suvanto-Luukkonen E. Perinatal Outcome of Children Born to Mothers with Thyroid Dysfunction or Antibodies: A Prospective Population -Based Cohort study. J Clin Endocrinol Metab 2009; 94(3):772-79. 


\section{Original Article}

COMPARISON OF MATERNAL AND PERINATAL OUTCOME IN PREGNANT WOMEN WITH HYPOTHYROIDISM

DIAGNOSED BEFORE CONCEPTION WITH HYPOTHYROIDISM DIAGNOSED DURING PREGNANCY

Basnet P, Aggrawal N, Suri V, Dutta P, Mukhopadhyay K

http://dx.doi.org/10.1210/jc.2008-1520 PMid:19106271

18. Casey BM, Dashe JS, Wells CE, McIntire DD, Byrd W, Leveno $K J$, Cunningham FG.Subclinical hypothyroidism and pregnancy outcomes. Obstet Gynaecol 2005;105,239- 45. http://dx .doi.org/10.1097/01.AOG.0000152345.99421.22 PMid:15684146

19. Blazer S, Moreh-WatermanY, Miller-Lotan R, Tamir A, Hochberg Z. Maternal Hypothyroidism May Affect Fetal Growth and Neonatal Thyroid Function.Obstet Gynecol 2003;102: 23241. http:// dx. doi. org /10.1016/S0029-7844 (03) 00513-1
20. Tan O Tina, Cheng $W$ Yvonne, Caughey B Aaron. Are Women who are treated for hypothyroidism at risk for pregnancy complications? Am JObstet Gynecol 2006; 194,e1-e3. http://dx.doi.org/10.1016/j.ajog.2005.11.028 PMid:16647887

21. Albovich M, Gutierrez S, Alcaraz G, Maccallini G, Garcia A, Levalle $O$. Overt and subclinical hypothyroidism complicating pregnancy. Thyroid 2002;12:63-8.http://dx.doi.org/ 10.1089 /105072502753451986 PMid:11838732

22. Blazer S, Moreh-WatermanY, Miller-Lotan R, Tamir A, Hochberg Z. Maternal Hypothyroidism May Affect Fetal Growth and Neonatal Thyroid Function. Obstet Gynecol 2003 ;102 :23241.http://dx.doi.org/10.1016/S0029-7844(03)00513-1 